\title{
INTERNATIONAL AND NATIONAL MECHANISMS FOR THE PROTECTION OF THE RIGHTS OF VICTIMS OF ARMED CONFLICT IN EASTERN UKRAINE
}

Maria Maistrenko

Kira Gorelkina

Yevdokiia Buzhdyhanchuk

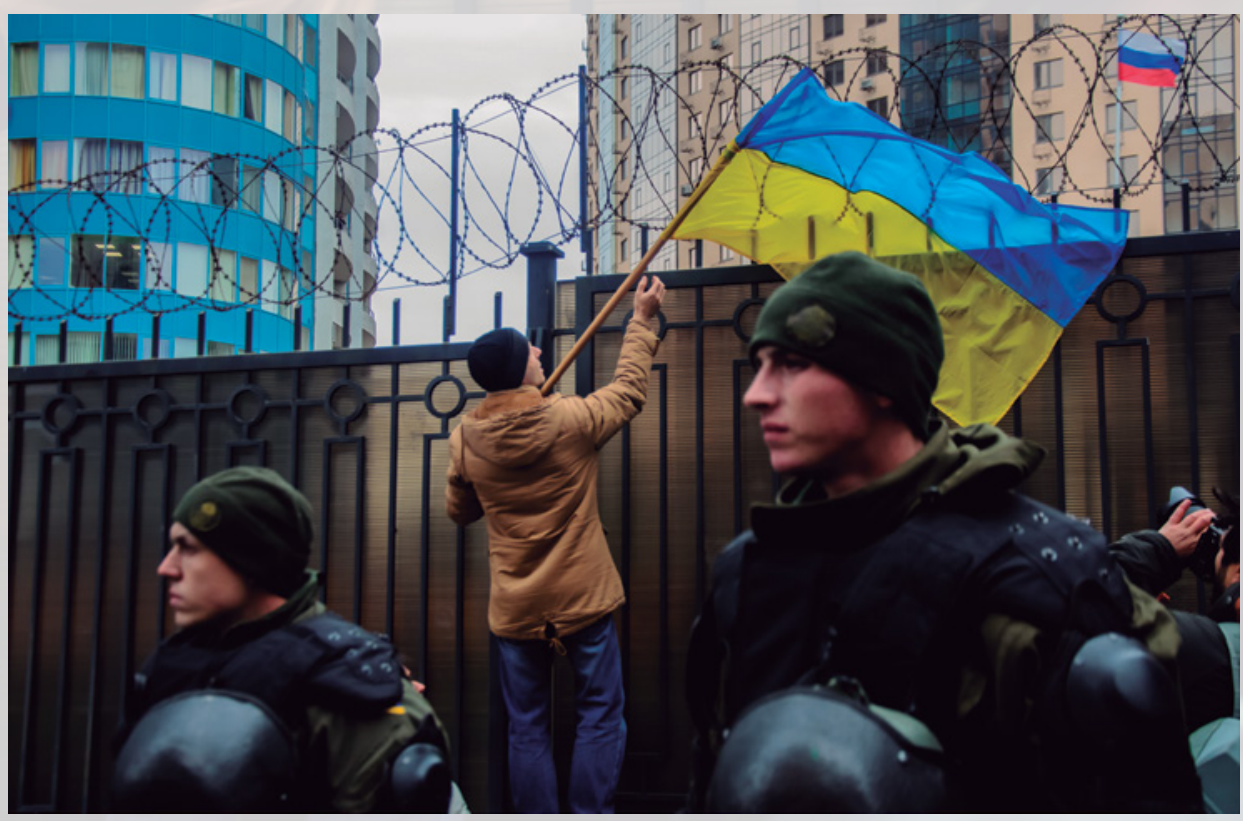





\title{
INTERNATIONAL AND NATIONAL MECHANISMS FOR THE PROTECTION OF THE RIGHTS OF VICTIMS OF ARMED CONFLICT IN EASTERN UKRAINE
}

\author{
Maria Maistrenko \\ Lviv State University of Internal Affairs, Lviv (Ukraine) \\ Kira Gorelkina \\ Educational and Scientific Humanitarian Institute, Kyiv (Ukraine) \\ YeVdokila BuZHDYHANCHUK \\ National Academy of Internal Affairs, Kyiv (Ukraine)
}

\begin{abstract}
Aiming to determine the implementation of constitutional rights and freedoms of citizens affected by the military conflict in Eastern Ukraine and to bring current legislation to world standards, this scientific article explores the main sources of international humanitarian law governing legal relations in armed aggressions, while the current state of protection of constitutional rights and freedoms of citizens affected by the armed conflict in Eastern Ukraine is examined. The methodological basis of the study consists of a set of general and special methods and techniques of scientific knowledge aimed at developing effective mechanisms to protect the rights of victims of armed conflict in Eastern Ukraine.
\end{abstract}

The study proposes that there is no effective mechanism for applying the provisions of relevant regulations on the protection of the fundamental rights and freedoms of the population during an international armed conflict. To this end, regulatory proposals have been developed to protect different categories of the population, such as women, children, prisoners of war, the wounded, and the sick. The main organizational measures at the national level include preventing and combating all forms of discrimination, gender-based violence, human trafficking, and slavery, while providing quality assistance to victims, conducting a timely investigation, and taking appropriate measures concerning any cases of damage, confiscation, and looting of property in the area of the Joint Forces Operation, as well as the commission of other criminal offenses. 
The article suggests ensuring adequate state guarantees for the protection of fundamental human rights to life; the existence of legal mechanisms for an effective investigation of violations of this right; freedom and personal integrity; an effective investigation of enforced disappearance crimes; the release of hostages, restoring their rights and ensuring their rehabilitation; as well as an independent, fair trial within a reasonable time.

Keywords: international armed conflict, violence, war crimes, victims, protection of rights.

About the authors: Maria Maistrenko, PhD in Law, senior professor at the Department of Criminal Procedure and Criminalistics, Lviv State University of Internal Affairs, Lviv (Ukraine). E-mail: justmarisabel2017@gmail.com

Gorelkina Kira, PhD in Law, Associate Professor at the Department of Public and Private Law, Educational and Scientific Humanitarian Institute, Kyiv (Ukraine).E-mail: cgorelkina@gmail.com

Buzhdyhanchuk Yevdokiia, PhD in Law, senior lecturer at the Department of Criminal Procedure, National Academy of Internal Affairs, Kyiv (Ukraine). E-mail: evdakia@ukr.net

Received: October 7, 2021; evaluated: October 20, 2021; accepted: November 15, 2021. 


\title{
MECANISMOS INTERNACIONALES Y NACIONALES PARA LA PROTECCIÓN DE LOS DERECHOS DE LAS VÍCTIMAS DE LOS CONFLICTOS ARMADOS EN EL ESTE DE UCRANIA
}

\author{
Maria Maistrenko \\ Lviv State University of Internal Affairs, Lviv (Ukraine) \\ Kira Gorelkina \\ Educational and Scientific Humanitarian Institute, Kyiv (Ukraine) \\ YEVDOKIIA BUZHDYHANCHUK \\ National Academy of Internal Affairs, Kyiv (Ukraine)
}

\section{Resumen}

Con el fin de determinar la implementación de los derechos y libertades constitucionales de los ciudadanos afectados por el conflicto militar en el este de Ucrania, y de llevar la legislación actual a los estándares mundiales, este artículo científico explora las principales fuentes del derecho internacional humanitario que rigen las relaciones legales en la agresión armada. Se tiene en cuenta el estado actual de protección de los derechos y libertades constitucionales de los ciudadanos afectados por el conflicto armado en el este de Ucrania.

La base metodológica de este trabajo estuvo conformada por los métodos y técnicas generales y especiales de conocimientos científicos destinados a desarrollar mecanismos eficaces para proteger los derechos de las víctimas de los conflictos armados en el este de Ucrania.

Se afirma que no existe un mecanismo eficaz para aplicar las disposiciones de la normativa pertinente sobre la protección de los derechos y libertades fundamentales de la población durante un conflicto armado internacional. Con este fin, se han desarrollado propuestas regulatorias para proteger a ciertas categorías de la población como mujeres, niños, prisioneros de guerra, heridos y enfermos. Las principales medidas organizativas escala nacional incluyen: prevenir y combatir todas las formas de discriminación, violencia de género, trata de personas y esclavitud, por medio de asistencia de 
calidad a las víctimas; la realización de una investigación oportuna y la adopción de las medidas apropiadas respecto de los casos de daños, decomiso y saqueo de bienes en el área de la Operación de Fuerzas Conjuntas, al igual que la comisión de otros delitos penales.

Se sugiere asegurar las garantías estatales adecuadas para la protección de los derechos humanos fundamentales a la vida y la existencia de mecanismos legales para la investigación efectiva de las violaciones a este derecho; a la libertad e integridad personal; a investigar eficazmente los delitos de desaparición forzada; a liberar a los rehenes, a restituir sus derechos y a asegurar su rehabilitación, y a un juicio imparcial e independiente en un plazo razonable.

Palabras clave: conflicto armado internacional, violencia, crímenes de guerra, víctimas, protección de derechos.

Los autores: Mariia Maistrenko, doctora en Derecho, profesora principal del Departamento de Procedimiento Penal y Criminalística de la Universidad Estatal de Asuntos Internos de Lviv, Lviv (Ucrania). Correo electrónico: justmarisabel2017@gmail.com

Gorelkina Kira, doctora en Derecho, profesora asociada del Departamento de Derecho Público y Privado, Instituto Humanitario Educativo y Científico, Kiev (Ucrania).Correo electrónico: cgorelkina@ gmail.com

Buzhdyhanchuk Yevdokiia, doctor en Derecho, profesor titular del Departamento de Procedimiento Penal, Academia Nacional de Asuntos Internos, Kiev (Ucrania).Correo electrónico: evdakia@ukr.net

Recibido: 7 de octubre de 2021; evaluado: 20 de octubre de 2021; aceptado: 15 de noviembre de 2021. 


\title{
MECANISMOS INTERNACIONAIS E NACIONAIS PARA A PROTEÇÃO DOS DIREITOS DAS VÍTIMAS DE CONFLITOS ARMADOS NO LESTE DA UCRÂNIA
}

\author{
Maria Maistrenko \\ Lviv State University of Internal Affairs, Lviv (Ukraine) \\ KiRA GORELKINA \\ Educational and Scientific Humanitarian Institute, Kyiv (Ukraine) \\ YEVDOKIIA BUZHDYHANCHUK \\ National Academy of Internal Affairs, Kyiv (Ukraine)
}

\section{Resumo}

A fim de determinar a implementação dos direitos e liberdades constitucionais dos cidadãos afetados pelo conflito militar no leste da Ucrânia, e para adequar a legislação atual aos padrões mundiais, este artigo científico explora as principais fontes do direito humanitário internacional que regem as relações jurídicas na agressão armada. O estado atual de proteção dos direitos constitucionais e liberdades dos cidadãos afetados pelo conflito armado no leste da Ucrânia é levado em conta.

A base metodológica deste trabalho foi moldada por métodos e técnicas gerais e especiais de conhecimento científico que visam desenvolver mecanismos eficazes para proteger os direitos das vítimas de conflitos armados no leste da Ucrânia.

Alega-se que não há mecanismo efetivo para implementar as disposições da legislação pertinente sobre a proteção dos direitos e das liberdades fundamentais da população durante um conflito armado internacional. Para isso, foram desenvolvidas propostas regulatórias para proteger certas categorias da população, como mulheres, crianças, prisioneiros de guerra, feridos e doentes. As principais medidas organizacionais em nível nacional incluem: prevenir e combater todas as formas de discriminação, violência de gênero, tráfico humano e escravidão, prestar assistência de qualidade às vítimas, conduzindo uma investigação oportuna e tomando as medidas cabíveis em casos de danos, confiscos e saques de bens na área da Operação de Forças Conjuntas, bem como a prática de outros crimes. 
Sugere-se assegurar garantias adequadas do Estado para a proteção dos direitos humanos fundamentais à vida e a existência de mecanismos legais para a efetiva investigação de violações desse direito; para a liberdade e integridade pessoal; para investigar efetivamente os crimes de desaparecimento forçado; para libertar os reféns, restaurar seus direitos e garantir sua reabilitação; e para dar um julgamento justo e independente dentro de um tempo razoável.

Palavras-chave: conflito armado internacional, violência, crimes de guerra, vítimas, proteção de direitos.

Os autores: Mariia Maistrenko, Doutora em Direito, professora sênior, Departamento de Processo Penal e Criminalística, Universidade Estadual de Assuntos Internos de Lviv, Lviv, Ucrânia. E-mail: justmarisabel2017@gmail.com

Gorelkina Kira, Doutora em Direito, professora associada, Departamento de Direito Público e Privado, Instituto Educacional Humanitário e Científico, Kiev, Ucrânia. E-mail: cgorelkina@gmail.com

Buzhdyhanchuk Yevdokiia, Doutor em Direito, professor pleno, Departamento de Processo Penal, Academia Nacional de Assuntos Internos, Kiev, Ucrânia. E-mail: evdakia@ukr.net

Recebido: 7 de outubro de 2021; avaliado: 20 de outubro de 2021; aceito: 15 de novembro de 2021. 


\section{Introduction}

The issues of constitutional and legal consolidation of the foundations of the individual-state relationship, recognition of the priority civil society development, as well as a clear legislative definition and proper practical guarantee of human rights and freedoms, play a particularly important role in any democratic state, especially in an internal armed conflict. These theoretical provisions are reflected in Article 3 of the Constitution of Ukraine, which stipulates that a person, his life and health, honor and dignity, inviolability and security, are recognized in our state as the highest social value. This constitutional norm also stipulates that human rights, freedoms, and guarantees determine the content and direction of the activities of the Ukrainian state. That is why the state has promised to take all measures to protect human rights and fundamental freedoms, guided by the case-law of the European Court of Human Rights and other sources of law that take precedence over national law.

Guaranteeing the rights and freedoms of the individual is the most important criterion for assessing the functioning of the state, which indicates its democratic (or undemocratic) nature. In Ukraine, this problem has become extremely important after the events of the Revolution of Dignity (November 2013 - February 2014), and since the occupation of Crimea and part of Donbass by the Russian Federation, it has transformed into a factor that significantly affects the national security. ${ }^{1}$ According to a report by the Office of the United Nations High Commissioner for Human Rights, the civilian population of Ukraine has paid the highest price due to significant human rights violations and abuses, insecurity and the collapse of the rule of law. ${ }^{2}$ During a military conflict, the population is subjected to massive informational and moral-psychological processing or used as an object for manipulation, in particular, when militants attack civilians to discredit the armed forces of a state that protects its sovereignty and territorial integrity. ${ }^{3}$

Reznikova, Olha; Semin, Serhii. Problems of protection of constitutional rights and freedoms of citizens of Ukraine during the settlement of the armed conflict in Donbass. 09/05/2017. 2.niss.gov.ua/content/articles/ files/konf_Dondas-157ee.pdf (accessed September 10, 2021).

2 Report on the human rights situation in Ukraine February 16 - May 15, 2016 Office of the United Nations High Commissioner for Human Rights. http://www.radnyk.org/uploads/7/6/6/5/76650087/ ukraine_14th_hrmmu_report_ukranian.pdf (accessed September 10, 2021).

3 Reznikova, Olha; Semin, Serhii. Problems of protection of constitutional rights and freedoms of citizens of Ukraine during the settlement of the armed conflict in Donbass. 09/05/2017. 2.niss.gov.ua/content/articles/ files/konf_Dondas-157ee.pdf (accessed September 10, 2021). 
According to foreign experts, the defining features of inadequate protection of the constitutional rights and freedoms of Ukrainian citizens in the uncontrolled territory, which are at the same time fundamental freedoms under international law, are violations of the right to free movement of citizens; to the right to freedom of thought and religion; to the right to peaceful assembly and freedom of association; to economic and social rights; rights to housing, land, and property; and the right to health care. ${ }^{4}$ Both in the case of traditional warfare and of hybrid or irregular conflicts, the population in the zone of armed conflict suffers from the violation of their fundamental human and civil rights. In such cases, there is not only a constant threat to the life, health and property of these people but their normal life is disturbed; they have several additional problems and responsibilities that are not inherent to peacetime.

The main reasons for this state of affairs with the inadequate implementation of the constitutional rights and freedoms of Ukrainian citizens living in the conflict zone include lack of financial resources of the state; lack of a clear selection mechanism and criteria for providing social support to migrants depending on their financial situation and social status; lack of complete and reliable information on the amount of damage (property damage) caused to displaced citizens during hostilities, and lack of a mechanism for their compensation; the imperfection of the state policy in the field for providing displaced citizens with jobs, and limited information on employment opportunities. Additionally, many displaced people have psychophysiological injuries and there is no program for providing them with appropriate medical and social assistance. ${ }^{5}$

Of course, the responsibility of any state for the fate of its citizens and the protection of their rights in any domestic political, socio-economic, and other circumstances is extremely high. Victory in a hybrid war on the territory of Ukraine can be achieved not only by purely military means, but also through a purposeful state policy aimed at consolidating Ukrainian society, in particular, through regulatory and equal rights and freedoms of all citizens, regardless of their place of residence,

4 According to the World Health Organization, in the unrecognized Donetsk People's Republic, approximately 62,000 children and adults need cancer treatment, of which nearly 10,000 are in critical condition. In total, more than 22,000 people living in the occupied territories in eastern Ukraine need daily insulin, which is in short supply. The psychological condition of approximately 400,000 children living in areas controlled by armed groups is alarming and needs specialized psychosocial support.

5 Reznikova, Olha; Semin, Serhii. Problems of protection of constitutional rights and freedoms of citizens of Ukraine during the settlement of the armed conflict in Donbass. 09/05/2017. 2.niss.gov.ua/content/articles/ files/konf_Dondas-157ee.pdf (accessed September 10, 2021). 
status, or electoral preferences. The issue of protection of civilians who have been tortured, or received inhuman and degrading treatment or punishment under the armed aggression of another state, as well as the protection of family members in the event of the death or disappearance of their loved ones is a question that lies on the plane legislative and organizational and legal initiatives of Ukraine, and must comply with the effective mechanisms of effective investigation of violations of the Criminal Code of Ukraine and international humanitarian law.

The above puts on the agenda and highlights the need to clarify international and national mechanisms for the protection of the rights of victims of armed conflict in eastern Ukraine, given the requirements of the world community. After all, this problem has long moved from the realm of purely theoretical discussions to the plane of practical ones.

\section{GENERAL CHARACTERISTICS OF SOURCES OF INTERNATIONAL HUMANITARIAN LAW THAT REGULATE LEGAL RELATIONS IN CONDITIONS OF ARMED AGGRESSION}

The main sources of international law are international treaties and international practices. Beginning in the third quarter of the nineteenth century, when the codification process of laws and war practices started, the international treaty became the main source of humanitarian law. Today, international humanitarian law is one of the most conventional branches of international law. It is important to note the extremely high level of commitment of states under multilateral agreements. This also applies to the settlement of relations in the field of protection of the rights of victims of armed conflict in eastern Ukraine.

Despite the legal uncertainty of the place of international practices in the Ukrainian legal system due to the absence of Art. 9 in its Constitution, - the reference to international customs- there is no doubt that Ukraine is bound by customary norms of international humanitarian law, along with the provisions of the Geneva Convention ${ }^{6}$ system of international legal obligations of Ukraine in the field of treatment and protection of victims of armed conflicts. This is confirmed by the provisions of the Law of Ukraine "On Principles of Domestic and Foreign Policy",

6 Geneva Convention relative to the Protection of Civilian Persons in Time of War. 12/08/1949. http://zakon4. rada.gov.ua/laws/show/995_154 (accessed September 10, 2021). 
according to which the principles of domestic and foreign policy are based on generally accepted principles and norms of international law (paragraph 1 of Article 2), and foreign policy is based on the following principles: man and his fundamental freedoms; conscientious fulfillment of the undertaken international obligations; priority of universally recognized norms and principles of international law over norms and principles of national law (paragraph 3 of Article 2).

Undoubtedly, the generally accepted norms and principles of international law include customary norms of international humanitarian law. General provisions on the binding nature of obligations under international treaties, approved by the Verkhovna Rada of Ukraine, are contained in the Law of Ukraine "On Defense of Ukraine" (parts 2, 5 of Article 2), the Military Doctrine of Ukraine (paragraph 2). The Rome Statute of the International Criminal Court of 16 January 2002 sets out the fundamental principles of non-discrimination and humane treatment and provides that everyone has the right to be respected for his or her dignity, religious beliefs, and practices in all situations. ${ }^{7}$ The provisions of the First Additional Protocol to the Geneva Conventions confirm the protection of civilians, the wounded and the sick, as well as prisoners of war and children. ${ }^{8}$ They extend the scope of such protection to any person who is under the authority of a party to the conflict and does not enjoy a more favorable treatment under the Geneva Conventions in the context of an international armed conflict. ${ }^{9}$

Several acts are prohibited and will remain so at any time and in any place, regardless of whether they are committed by representatives of civilian or military bodies (violence against life, health and physical and mental condition of persons; abuse of human dignity hostage-taking, collective punishment, coercion into prostitution or indecent assault in any form. ${ }^{10}$ Some of them are considered serious violations of international humanitarian law, such as murder, torture, mutilation, and hostage-taking (serious violations of the Geneva Conventions and the Additional

7 Constitution of Ukraine, Art. 3, 11, 27, 28, 29, 32 (1), 35, 51 (3); Criminal Procedure Code of Ukraine, Art. 7, 8, 10, 11, 15 .

8 Additional Protocol I to the Geneva Conventions of 12/08/1949, concerning the Protection of Victims of International Armed Conflicts (Protocol I) of 8/06/1977. https://zakon.rada.gov.ua/laws/show/995_199 (accessed September 10, 2021).

9 Additional Protocol I to the Geneva Conventions of 12/08/1949, concerning the Protection of Victims of International Armed Conflicts (Protocol I) of 8/06/1977. https://zakon.rada.gov.ua/laws/show/995_199 (accessed September 10, 2021).

10 Additional Protocol to the Geneva Conventions of 12/08/1949, concerning the Protection of Victims of non-International Armed Conflicts of 8/06/1977. http://zakon0.rada.gov.ua/laws/show/995_200 (accessed September 10, 2021). 
protocol $)^{11}$; abuse of human dignity, collective punishment, and the commission of sexual violence, including coercion into prostitution (war crimes under customary international humanitarian law), for which criminal liability should be provided.

According to the analysis of investigative and judicial practice and the scientific literature, the main victims in the context of international armed conflict belong to population categories such as women, children, and prisoners of war, wounded and sick. Fundamentally, new social groups of people who also need state protection and support include civilians who have not been directly involved in the armed conflict but are suffering from hostilities and the inability to protect their rights, including the population who live in the conflict zone ${ }^{12}$, such as disabled people whose handicap is due to injuries or other damage caused to their health in areas of hostilities; persons who were injured or damage in their health also in hostility areas, but who did not become disabled; family members of citizens who disappeared or died as a result of injuries or other damage caused to their health in confrontation areas; persons who have suffered exclusively material damage occurring in those areas; and internally displaced persons.

A brief description will be given of the provisions of international regulations aimed at protecting the rights of victims of international armed conflicts, in order to develop effective mechanisms for their protection at the national level. Under the First Additional Protocol, women are given special protection when their freedom is restricted for reasons related to armed conflict. In particular, they must be kept in rooms separate from those for men (or if women are part of families, such women are kept in the same room with their families), and they are under the direct supervision of women. ${ }^{13}$ Cases of pregnant women and mothers of young children

11 The report estimates that between 2014 and 2021, some 4,000-conflict detainees (approximately 3,400 men and about 600 women) were victims of torture and ill-treatment, including approximately 340 victims of sexual violence. The report emphasizes the prevailing impunity of violators due to the lack of effective investigations into allegations of arbitrary detention, torture and ill-treatment, including conflict-related sexual violence. This means that victims' right to redress and reparation remains largely unrealized.

12 According to the thirty-first report of the United Nations on the human rights situation in Ukraine for the period from August 1, 2020 to January 31, 2021, three civilians were wounded as a result of active hostilities using small arms and light weapons. The victims of mine explosions and explosive remnants of war were 36 civilians (eight dead and 28 wounded). Since the beginning of the conflict, the Office of the United Nations High Commissioner for Human Rights has recorded 3,375 civilian deaths. There were also 18 new attacks on journalists and other media workers, human rights defenders, civic and political activists, members of national minorities or their supporters, and politicians of opposition political parties considered "pro-Russian".

13 Additional Protocol to the Geneva Conventions of 12/08/1949, concerning the Protection of Victims of non-International Armed Conflicts of 8/06/1977. http://zakon0.rada.gov.ua/laws/show/995_200 (accessed September 10, 2021). 
depending on them who are arrested, detained, or interned for reasons related to armed conflict, are considered a matter of priority. ${ }^{14}$ International humanitarian law places a well-known emphasis in its provisions on the protection of women, in particular, protection against rape, coercion into prostitution, or any other form of encroachment on their morality. ${ }^{15}$ Thus, the commission of sexual violence states that rape, in particular (Article 152 of the Criminal Code of Ukraine), and pimping or involving a person in prostitution (Article 303 of the Criminal Code of Ukraine $)^{16}$, constitutes a serious violation of international humanitarian law, following its customary norms.

The First and Second Geneva Conventions require governments to protect and respect members of the armed forces who are wounded or ill during armed conflict. ${ }^{17}$ It should be noted that Art. 12 of these conventions applies to the sick and wounded of Ukrainian servicemen, as well as to the wounded, sick and shipwrecked, who are part of the enemy forces (for example, prisoners of war). It undertakes to ensure humane treatment and care without any discrimination on grounds of sex, race, nationality, religion, political opinion, or other similar criteria. ${ }^{18}$ Ukraine is obliged to prohibit any attempt on the life of the sick and wounded, or any violence against them, i.e. to kill and destroy, torture, or conduct biological experiments. It is forbidden to intentionally leave such persons without medical care and services, or to intentionally create conditions for their infection or re-infection. ${ }^{19}$ In conditions of armed conflict, one of the common categories of victims of war is prisoners of war. The Third Geneva Convention stipulates that prisoners of war always have

14 Additional Protocol I to the Geneva Conventions of 12/08/1949, concerning the Protection of Victims of International Armed Conflicts (Protocol I) of 8/06/1977. https://zakon.rada.gov.ua/laws/show/995_199 (accessed September 10, 2021).

15 Geneva Convention relative to the Protection of Civilian Persons in Time of War. 12/08/1949. http://zakon4. rada.gov.ua/laws/show/995_154 (accessed September 10, 2021). Art. 27.

16 Guide to the Application of International Humanitarian Law in the Armed Forces of Ukraine: Order of the Minister of Defense of Ukraine. 11/09/2004 No 400. Kyiv: Azimut-Ukraine, 2004.

17 Convention for the Amelioration of the Condition of the Wounded and Sick in Armed Forces. 12/08/1949. http://zakon4.rada.gov.ua/laws/show/995_151 (accessed September 10, 2021). ст.12 (1); Geneva Convention for the Amelioration of the Condition of the Wounded, Sick and Shipwrecked in the Armed Forces at Sea. 12/08/1949. http://zakon0.rada.gov.ua/laws/show/995_152 (accessed September 10, 2021). Art. 12(1).

18 Convention for the Amelioration of the Condition of the Wounded and Sick in Armed Forces. 12/08/1949. http://zakon4.rada.gov.ua/laws/show/995_151 (accessed September 10, 2021). Art. 12 (1); Geneva Convention for the Amelioration of the Condition of the Wounded, Sick and Shipwrecked in the Armed Forces at Sea. 12/08/1949. http://zakon0.rada.gov.ua/laws/show/995_152 (accessed September 10, 2021), Art. 12 (1).

19 Convention on the Amelioration of the Condition of the Wounded and Sick in Armed Forces. 1949-08-12. Official site of the Verkhovna Rada of Ukraine. http://zakon4.rada.gov.ua/laws/show/995_151 (accessed September 10, 2021). ст.12 (1); Convention for the Amelioration of the Condition of the Wounded and Sick in Armed Forces. 12/08/1949. http://zakon4.rada.gov.ua/laws/show/995_151 (accessed September 10, 2021). Art. 12 (1). 
the right to humane treatment. International humanitarian law prohibits subjecting them to physical injury or medical/scientific experiments of any kind that are not justified by the need for medical, dental, or in-patient treatment of a prisoner of war, and requires liability for such acts. ${ }^{20}$

The main international legal instrument defining the rights of children is the Convention on the Rights of the Child, Art. 38 which stipulates that all States parties are obliged to take all possible measures to ensure the protection and care of children affected by armed conflict. ${ }^{21}$ The protection of children in armed conflict is also governed by the Geneva Convention relative to the Protection of Civilian Persons in Time of War and Additional Protocols I and II. In particular, the Convention emphasizes that children have the right, under all circumstances, to personal respect, respect for their honor, the right to a family, their religious beliefs and rites, habits and customs. They should always be treated humanely and protected, in particular from any act of violence or intimidation, from the insults and curiosity of the crowd..$^{22}$ It should be noted that the above obligations arising from the Convention on the Rights of the Child, the Optional Protocol thereto, as well as customary international law, also apply during non-international armed conflict. In particular, the recruitment of children under the age of 15 into the armed forces, or their use for active participation in hostilities is also considered a serious violation of international humanitarian law during a non-international armed conflict in accordance with customary international humanitarian law and Article 8 of the Rome Statute Criminal court. ${ }^{23}$

If we talk about the prosecution of perpetrators of criminal offenses, then, in our opinion, it is indisputable that the application of criminal law at the national level should focus on the practice of international criminal courts, doctrine, authoritative comments on international commercial law, and international treaties. However, the list of acts that may consider violations of the laws and customs of war does not necessarily coincide with the list of Art. 8 of the Rome Statute, or a list of serious violations of international economic law. It can be extended, but not arbitrarily. In

20 Geneva Convention relative to the Treatment of Prisoners of War. 12/08/1949. http://zakon5.rada.gov.ua/ laws/show/995_153, ст. 13 (accessed September 10, 2021). Art. 13.

21 Convention on the Rights of the Child. 20/11/1989. https://zakon.rada.gov.ua/laws/show/995_021 (accessed September 10, 2021).

22 Geneva Convention relative to the Protection of Civilian Persons in Time of War. 12/08/1949. http://zakon4. rada.gov.ua/laws/show/995_154 (accessed September 10, 2021).

23 Rome Statute of the International Criminal Court. 16/01/2002. https://zakon.rada.gov.ua/laws/show/995_588 (accessed September 10, 2021). 
any case, the expansion of the list of these acts should find support on international practice. Otherwise, Ukraine will almost certainly face cases against itself in the European Court of Human Rights.

\section{NATIONAL MECHANISMS FOR REGULATION OF PROTECTION OF THE RIGHTS OF VICTIMS OF THE INTERNATIONAL ARMED CONFLICT IN EASTERN UKRAINE}

At the national level, the basic guarantees for the protection of a person provided by the constitution of Ukraine are, namely: everyone, under any circumstances, has the right to life and inviolability, to personal respect, respect for their honor, their religious beliefs, the right to have a family, etc. Other fundamental human rights norms regulated by other legal acts, in particular, but not exclusively, are the Criminal Code of Ukraine, the Civil Protection Code, the Law of Ukraine "On the Armed Forces of Ukraine", the Law of Ukraine "On Ensuring the Rights and Freedoms of Citizens and the Legal Regime" territory of Ukraine", the Law of Ukraine" On ensuring the rights and freedoms of internally displaced persons".

Also today, several regulations define the features of public administration in eastern Ukraine and are designed to provide social protection for the local population. In particular, these are Laws of Ukraine "On temporary measures for the period of anti-terrorist operation, "On ensuring the rights and freedoms of internally displaced persons", acts of the Cabinet of Ministers of Ukraine on approval of the list of settlements on the territories where the Joint Forces Operation was carried out, on the creation of the State Agency for Donbass Reconstruction, on the restriction of supplies of certain goods (works, services) from the temporarily occupied territory to another territory of Ukraine, on approval of the comprehensive state program on support, social adaptation and reintegration of citizens of Ukraine who moved from the temporarily occupied territory of Ukraine to other regions of the country, etc.

In addition, the basic principles of implementation of the state policy on the protection of constitutional rights and freedoms of Ukrainian citizens and the practical mechanisms for this implementation are defined by the National Strategy in the field of human rights ${ }^{24}$ and the Action Plan for the Implementation of the

24 National Strategy in the Sphere of Human Rights: Decree of the President of Ukraine. 24/03/2021. № 119/2021. https://zakon.rada.gov.ua/laws/show/119/2021\#n13 (accessed September 10, 2021). 
National Strategy for Human Rights for 2021-2023. ${ }^{25}$ These strategic documents, in particular, state that the improvement of the system for ensuring and protecting human rights and freedoms will be carried out taking into account both the domestic experience and the principles and approaches developed and tested by the international community. In this regard, the experience of the Ukrainian Parliament's Commissioner for Human Rights, the European Union, the United Nations, the European Council, the Organization for Security and Cooperation in Europe, other international organizations, and the law-case of the European Court of Justice will be taken into account; also, the experience of human rights organizations in Ukraine will be actively used. In cooperation with other states, Ukraine applies an approach based on human rights and freedoms, develops multilateral relations taking into consideration international obligations in this area. ${ }^{26}$ Therefore, to say that the state of Ukraine is not doing anything to protect its citizens at the legislative level in connection with the armed conflict in the east is incorrect. ${ }^{27}$

In our opinion, the main problem is not only the lack of a sufficient number of relevant regulations or the imperfection of their provisions on the protection of fundamental rights and freedoms of the population during international armed conflict (although there is enough work to improve the existing legislation), but also is the absence of an effective mechanism for their use. In substantiation of the stated considerations, we will carry out the scientific analysis of the national provisions regulating public relations in this sphere. The analysis of the current legislation of Ukraine, which is designed to protect the constitutional rights and freedoms of Ukrainian citizens during the international armed conflict in eastern Ukraine, suggests that the issues of their guarantee and implementation are regulated in detail for such categories of Ukrainian citizens as servicemen and employees following the laws of Ukraine of military formations that protected the independence, sovereignty and territorial integrity of Ukraine and took a direct part in the anti-terrorist operation (ensuring its implementation) ${ }^{28}$

25 On approval of the action plan for the implementation of the National Strategy in the field of human rights for 2021-2023. Order of the Cabinet of Ministers of Ukraine. 23/06/2021. № 756-P. https://zakon.rada. gov.ua/laws/show/756-2021-\%D1\%80 (accessed September 10, 2021).

26 National Strategy in the Sphere of Human Rights: Decree of the President of Ukraine. 24/03/2021. No 119/2021. https://zakon.rada.gov.ua/laws/show/119/2021\#n13 (accessed September 10, 2021).

27 Executed in Donbass: facts of torture and murder in eastern Ukraine. Online article. 06/06/2017. http:// book.mb.net.ua/visnovki-ta-rekomindaci\%D1\%97 (accessed September 10, 2021).

28 On the status of war veterans, guarantees of their social protection: Law of Ukraine. 22/10/1993. No 3551-XII. http://zakon2.rada.gov.ua/laws/show/3551-12 (accessed September 10, 2021). 
The Criminal Executive Code of Ukraine and the Criminal Procedure Code of Ukraine define specific mechanisms for the protection of women and families in peacetime. However, although these provisions were not intended to apply during armed conflict, they remain relevant today as they can be applied to implement international humanitarian law and be an informative source of recommendations for an appropriate approach. In particular, the Penal Code provides for the separate detention of women and men during detention. ${ }^{29}$ In addition, the Criminal Procedure Code of Ukraine in Art. 535 stipulates that imprisonment may be postponed in case of pregnancy of a convicted person or if she has a child under the age of three. ${ }^{30}$

Concerning the establishment of criminal liability for serious violations of international humanitarian law, it should be noted that the content of the provisions of Art. 438 (Violation of laws and customs of war) of the Criminal Code of Ukraine is generalized enough to cover the full range of such serious violations as, for example, murder, torture, hostage-taking, pimping, or involving a person in prostitution, etc. In our opinion, the level of detail of Art. 438 of the Criminal code of Ukraine is insufficient. There is a high probability that such an edition does not provide the accuracy and specificity that underlies effective prosecution for appropriate forms of prohibited conduct. Also, the Guidelines for the Application of International Humanitarian Law in the Armed Forces of Ukraine do not stipulate that rape, coercion into prostitution and any other form of encroachment on a person's morality constitutes a serious violation of international humanitarian law. ${ }^{31}$

The fundamental principles of non-discrimination and humane treatment are enshrined in the Constitution of Ukraine and therefore apply at any time, including wounded and sick persons from among the personnel of the armed forces. ${ }^{32}$ At the constitutional level, the basic judicial guarantees applicable to prisoners of war are defined (for example, the right to be immediately informed of the reasons why

29 Criminal Enforcement Code of Ukraine: Law of Ukraine. 11/07/2003. № 1129-IV. https://zakon.rada.gov. ua/laws/show/1129-1 (accessed September 10, 2021).

30 Criminal Procedure Code of Ukraine: Law of Ukraine. 13/04/2012. N 4651-VI. https://zakon.rada.gov.ua/ laws/show/4651-17 (accessed September 10, 2021).

31 Guide to the Application of International Humanitarian Law in the Armed Forces of Ukraine: Order of the Minister of Defense of Ukraine. 11/09/2004 № 400. Kyiv: Azimut-Ukraine, 2004.

32 Constitution of Ukraine: Law of Ukraine. 28/06/1996. № 254k/96-vr. http://zakon3.rada.gov.ua/laws/ show/254к/96-вр (accessed September 10, 2021). Art. 21, 24, 28. Criminal Code of Ukraine: Law of Ukraine. 05/04/2001. No 2341-III. http://zakon5.rada.gov.ua/laws/show/2341-14/print1469257658644343. (Accessed September 10, 2021). Art.161. 
measures have been taken, the presumption of innocence, right to consultation). ${ }^{33}$ At the same time, the specific requirements related to the status of prisoners of war remain unresolved by law. Concerning acts that equate to serious violations of international humanitarian law, Art. 434 of the Criminal code of Ukraine unambiguously establishes criminal liability for ill-treatment of wounded and sick prisoners of war as for a war crime, and also for the careless performance of duties to the wounded and sick by persons who are obliged to provide them with medical care. The procedure for prosecuting such acts often depends on law enforcement practice.

At the same time, it should be noted that in addition to these provisions, Ukrainian legal remedies do not reflect many requirements of international humanitarian law, including procedures for detention pending trial; protection rights, such as the right to call witnesses and have an interpreter; and the preconditions for the execution of the sentence and the necessary guarantees, such as the impossibility of depriving the detainee of the privileges conferred by his rank, or the right to exercise and to be in the fresh air for at least two hours. Although the basic judicial guarantees are provided by the Constitution of Ukraine, the Criminal Code, and the Code of Criminal Procedure, these legal acts do not take into account the special requirements related to the status of prisoners of war. Other enforcement measures are improperly defined, making it impossible to ensure a comprehensive implementation regime for the use of criminal penalties for prisoners of war (e.g. notification of proceedings, individual rights and remedies, conditions of sentence, right to appeal, execution, etc.).

With regard to the special protection of children during armed conflict, the Law of Ukraine "On Child Protection" provides for the general protection of children during armed conflict. The amendments set out specific measures to protect children affected by hostilities or armed conflict, such as specific social service obligations. ${ }^{34} \mathrm{~A}$ child who has suffered as a result of hostilities and armed conflicts is a category defined in the Law of Ukraine "On Child Protection". The law provides for the possibility of obtaining the status of a child who has suffered as a result of hostilities and armed conflicts. ${ }^{35}$ Entitled to receive this status are children and

Constitution of Ukraine: Law of Ukraine. 28/06/1996. № 254k/96-vr. http://zakon3.rada.gov.ua/laws/ show/254k/96-BP (accessed September 10, 2021).

34 On Child Protection: Law of Ukraine. 26/04/2001. № 2402-III. https://zakon.rada.gov.ua/laws/show/240214 (accessed September 10, 2021).

35 Procedure for granting the status of a child affected by hostilities and armed conflicts: Resolution of the Cabinet of Ministers of Ukraine. 05/04/2017. № 268. https://zakon.rada.gov.ua/laws/show/268-2017-\%D0\%BF 
persons who at the time of the war were not 18 years of age (adults) and who, as a result of hostilities and armed conflicts, suffered wounds, contusions, or injuries; experienced physical and sexual violence; were abducted or illegally taken out of Ukraine; were involved in the actions of paramilitary or armed formations; were illegally detained, also in captivity, and were victims of psychological violence.

In this segment, Ukraine is taking all necessary and possible measures to search for and return to Ukraine children who have been illegally taken abroad, including in connection with circumstances related to hostilities and armed conflicts. ${ }^{36}$ In particular, the new Article 30-1 of the Law of Ukraine "On Child Protection" concerns the protection of children who are in the zone of hostilities and armed conflicts, as well as children who have suffered as a result of these confrontations. There are several legal acts in force in Ukraine (the Law of Ukraine "On Child Protection" and the Law of Ukraine "On Military Duty and Military Service"), aimed at regulating the use of children during armed conflicts. Their provisions seem to further detail Art. 438 of the Criminal code of Ukraine.

However, in general, Ukrainian remedies do not contain sufficiently detailed provisions on prohibited actions and the nature of criminal punishment. In particular, although the provisions state that the use of child soldiers and their compulsory conscription is prohibited, the provisions do not explain the severity of the serious violation of international humanitarian law resulting from the conscription and use of children (without coercion or obligation), for the commission of which it is necessary to apply criminal punishment. Analysis of criminal remedies for children victims of crimes committed in armed conflict leads to the conclusion that Art. 438 of the Criminal Code of Ukraine is sufficiently voluminous to ensure the prosecution of persons responsible for conscription and use of children for military service ${ }^{37}$. This approach to criminalization is common and does not detail the process, which is the basis for effective prosecution for crimes committed in armed conflict.

Given the proposal repeatedly expressed in the scientific literature and substantiated by us in the scientific article on the detail in criminal law of certain illegal acts, which are now artificially covered by Article 438 (Violation of laws and customs of

(accessed September 10, 2021).

36 On Child Protection: Law of Ukraine. 26/04/2001. N²402-III. https://zakon.rada.gov.ua/laws/show/2402-14 (accessed September 10, 2021).

37 Criminal Code of Ukraine: Law of Ukraine. 05/04/2001. N ${ }^{\circ}$ 2341-III. http://zakon5.rada.gov.ua/laws/ show/2341-14/print1469257658644343 (accessed September 10, 2021). 
war) of the Criminal Code, we propose to focus on the list of violation of the laws and customs of war, proposed in the bill "On Amendments to Certain Legislative Acts of Ukraine to Ensure Harmonization of Criminal Law with the Provisions of International Law" $\mathrm{N}^{\circ} 9438^{38}$. This is, in particular, Art. 437 "Aggression", Art. Ст. $437^{1}$ "Crimes against humanity", Art. 438 "War crimes against persons", Art. $438^{1}$ "War crimes against justice", Art. 4382 "War crimes against property", Art. $438^{3}$ "War crimes against humanitarian operations and the use of symbols", Art. $438^{4}$ "War crimes, consisting of the use of prohibited methods of warfare", Art. $438^{5}$ "War crimes, consisting of the use of prohibited means of warfare", Art. $438^{6}$ "War crimes against movable and immovable property, buildings and centers under protection under international humanitarian law", Art. $436^{2}$ "Peculiarities of criminal liability for crimes against the foundations of international law", Section XXI "Crimes against the international law").

This list of actions is at least conceptually in line with international standards and Ukraine's obligations under international treaties to criminalize violations of international humanitarian law. We believe that the relevant amendments to the Criminal Code will undoubtedly help protect the rights of victims of armed conflict in eastern Ukraine, in particular, for obtaining the status of a victim in criminal proceedings, and thus allow the use of the mechanism of compensation for such crimes.

In view of the prospects of our problem of developing legal mechanisms to restore the rights of victims violated by armed aggression in eastern Ukraine, the provisions of one of the draft Laws of Ukraine "On Protection of Property Rights and Other Real Rights of Victims of Armed Aggression"139 are progressive. The purpose of this law is to protect the property rights of persons violated by armed aggression through the introduction of restitution mechanisms, as well as compensation for property damage caused to them in accordance with international and European human rights standards, including the law-case of the European Court of Human Rights. One of the main advantages of this bill is that if it is adopted, the conditions of receipt, grounds for refusal, amount of compensation, etc. will be introduced by law, the rules of which will have higher legal force compared to the Cabinet

On Amendments to Certain Legislative Acts of Ukraine Concerning Ensuring Harmonization of Criminal Legislation with Provisions of International Law: Draft Law. 20/12/2018. № 9438. http://w1.cl.rada.gov. ua/pls/zweb2/webproc4_1?pf3511=65266 (accessed September 10, 2021).

39 On Amendments to Certain Legislative Acts of Ukraine Concerning Ensuring Harmonization of Criminal Legislation with Provisions of International Law: Draft Law. 20/12/2018. № 9438. http://wl.cl.rada.gov. ua/pls/zweb2/webproc4_1?pf3511=65266 (accessed September 10, 2021). 
of Ministers. At the same time, the development of relevant bylaws to implement the provisions of the law will create a full-fledged, comprehensive compensation mechanism. In addition, the existence of a legislative mechanism will facilitate the proper implementation of Ukraine's international legal obligations under international treaties. ${ }^{40}$

Thus, it is concluded that the current nature and consequences of armed conflicts, including hybrid ones, require the improvement of Ukrainian legislation to fully ensure the rights, freedoms, life, and health of the affected civilian population, as well as humane treatment without any discrimination against persons who did not directly take part in hostilities, as well as for those who voluntarily laid down their arms under Article 3 of the Geneva Convention. Finally, we note that we have considered only a separate segment of the global complex problem - the protection of the rights and legitimate interests of victims of armed conflict in eastern Ukraine by means of international and national law-. Problematic issues related to the social, medical, psychological, and material support of the affected families, primarily in terms of compensation for property (material) and moral damage, remain in need of detailed analysis.

\section{CONCLUSIONS}

In order to determine the areas to ensure the implementation of the constitutional rights and freedoms of citizens affected by the military conflict in eastern Ukraine, bringing the current legislation of Ukraine to world standards, the following conclusions are drawn:

1. It is stated that there is no effective mechanism for applying the provisions of the relevant regulations on the protection of fundamental rights and freedoms of the population during the international armed conflict in eastern Ukraine. The main organizational measures at the national level include: preventing and combating all forms of discrimination, gender-based violence, human trafficking and slavery, and providing quality assistance to victims; conducting a timely investigation and taking appropriate measures concerning any cases of damage, confiscation, and looting of property in the area of the Joint Forces Operation, the commission of other criminal offenses.

40 Explanatory note to the Law on Protection of Property Rights and Other Real Rights of Persons Victims of Armed Aggression. 01/03/2021 N 5177.https://wl.cl.rada.gov.ua/pls/zweb2/webproc4_1?pf351l=71272 (accessed September 10, 2021). 
2. The Government of Ukraine needs to consider ensuring adequate funding for the measures envisaged by the National Strategy for Human Rights for 2021-2023. When implementing the National Human Rights Strategy, it is advisable to pay attention to the need to ensure adequate state guarantees for the protection of fundamental human rights (in particular, such categories as women, children, prisoners of war, wounded and sick): life and legal mechanisms to effectively investigate violations rights; to freedom and personal integrity, to effectively investigate the crimes of enforced disappearance, to release hostages, to restore their rights and to ensure their rehabilitation; to an independent, fair court within a reasonable time that meets international human rights standards.

3. In order for Ukraine to comply with the requirements of international humanitarian law, the following should be defined at the legislative level: 1) the Guide to the Application of International Humanitarian Law in the Armed Forces of Ukraine, with mothers of young children, for reasons related to armed conflict; 2) procedures for detainees pending trial, the right to defense (the right to call witnesses and have an interpreter; the preconditions for the execution of the sentence and the necessary guarantees of air for at least two hours); 3) at the constitutional level - provisions that will determine the status of prisoners of war; relevant legal norms (separate corpus delicti) in the Criminal Code of Ukraine, which would correspond to socially dangerous acts committed in the context of an international armed conflict ("Aggression", "Crimes against humanity", "War crimes against persons", "War crimes against justice", "War crimes against property", "War crimes against humanitarian operations and the use of symbols", etc.); 4) the opportunity to enjoy special protection due to the status of the child in the case of direct participation in hostilities and capture, as well as in the case of arrest, detention or internment for reasons related to armed conflict, etc.).

\section{REFERENCES}

Additional Protocol I to the Geneva Conventions of 12/08/1949, concerning the Protection of Victims of International Armed Conflicts (Protocol I) of 8/06/1977. https://zakon. rada.gov.ua/laws/show/995_199\#Text. (Accessed September 10, 2021).

Additional Protocol to the Geneva Conventions of 12/08/1949, concerning the Protection of Victims of non-International Armed Conflicts of 8/06/1977. http://zakon0. rada. gov.ua/laws/show/995_200. (Accessed September 10, 2021). 
Report on the human rights situation in Ukraine February 16 - May 15, 2016 Office of the United Nations High Commissioner for Human Rights. http://www.radnyk.org/ uploads/7/6/6/5/76650087/ukraine_14th_hrmmu_report_ukranian.pdf. (Accessed September 10, 2021).

Geneva Convention relative to the Protection of Civilian Persons in Time of War. 12/08/1949. http://zakon4.rada.gov.ua/laws/show/995_154. (Accessed September 10, 2021).

Geneva Convention relative to the Treatment of Prisoners of War. 12/08/1949. http:// zakon5.rada.gov.ua/ laws/show/995_153, ст. 13. (Accessed September 10, 2021).

On the status of war veterans, guarantees of their social protection: Law of Ukraine. 22/10/1993. No 3551-XII. http://zakon2.rada.gov.ua/laws/show/3551-12. (Accessed September 10, 2021).

Guide to the Application of International Humanitarian Law in the Armed Forces of Ukraine: Order of the Minister of Defense of Ukraine. 11/09/2004 No 400. Kyiv: Azimut-Ukraine, 2004.

Convention for the Amelioration of the Condition of the Wounded and Sick in Armed Forces. 12/08/1949. http://zakon4.rada.gov.ua/laws/show/995_151. (Accessed September 10, 2021).

Geneva Convention for the Amelioration of the Condition of the Wounded, Sick and Shipwrecked in the Armed Forces at Sea. 12/08/1949. http://zakon0.rada.gov.ua/ laws/show/995_152. (Accessed September 10, 2021).

Convention on the Rights of the Child. 20/11/1989. https://zakon.rada.gov.ua/laws/ show/995_021. (Accessed September 10, 2021).

Constitution of Ukraine: Law of Ukraine. 28/06/1996. N²54k/96-vr. http://zakon3.rada. gov.ua/laws/show/254K/96-вP. (Accessed September 10, 2021).

Criminal Code of Ukraine: Law of Ukraine. 05/04/2001. No 2341-III. http://zakon5.rada. gov.ua/laws/show/2341-14/print1469257658644343. (Accessed September 10, 2021).

Criminal Procedure Code of Ukraine: Law of Ukraine. 13/04/2012. No 4651-VI. https:// zakon.rada.gov.ua/laws/show/4651-17. (Accessed September 10, 2021).

Criminal Enforcement Code of Ukraine: Law of Ukraine. 11/07/2003. N 1129-IV. https:// zakon.rada.gov.ua/laws/show/1129-15. (Accessed September 10, 2021).

National Strategy in the Sphere of Human Rights: Decree of the President of Ukraine. 24/03/2021. No 119/2021. https://zakon.rada.gov.ua/laws/show/119/2021\#n13. (Accessed September 10, 2021).

New UN report on human rights: arbitrary detention, torture and ill-treatment in Ukraine must end. Online article. 02/07/2021. https://ukraine.un.org/uk/134308-nova-dopovid-oon-z-prav-lyudyny-svavilni-zatrymannya-katuvannya-i-zhorstoke-povodzhennya-v. (Accessed September 10, 2021). 
Procedure for granting the status of a child affected by hostilities and armed conflicts: Resolution of the Cabinet of Ministers of Ukraine. 05/04/2017. N 268. https:// zakon.rada.gov.ua/laws/show/268-2017-\%D0\%BF. (Accessed September 10, 2021).

Explanatory note to the Law on Protection of Property Rights and Other Real Rights of Persons Victims of Armed Aggression. 01/03/2021 No 5177. https://wl.cl.rada.gov. ua/pls/zweb2/webproc4_1?pf3511=71272. (Accessed September 10, 2021).

On approval of the action plan for the implementation of the National Strategy in the field of human rights for 2021-2023. Order of the Cabinet of Ministers of Ukraine. 23/06/2021. No 756-p. https://zakon.rada.gov.ua/laws/show/756-2021-\%D1\%80. (Accessed September 10, 2021).

On Child Protection: Law of Ukraine. 26/04/2001. N 2402-III. https://zakon.rada.gov. ua/laws/show/2402-14. (Accessed September 10, 2021).

Reznikova, Olha; Semin, Serhii. Problems of protection of constitutional rights and freedoms of citizens of Ukraine during the settlement of the armed conflict in Donbass. 09/05/2017. 2.niss.gov.ua/content/articles/files/konf_Dondas-157ee.pdf. (Accessed September 10, 2021).

On Amendments to Certain Legislative Acts of Ukraine Concerning Ensuring Harmonization of Criminal Legislation with Provisions of International Law: Draft Law. 20/12/2018. No 9438. http://wl.cl.rada.gov.ua/pls/zweb2/webproc4_1?pf3511=65266. (Accessed September 10, 2021).

Rome Statute of the International Criminal Court. 16/01/2002. https://zakon.rada.gov.ua/ laws/show/995_588. (Accessed September 10, 2021).

Executed in Donbass: facts of torture and murder in eastern Ukraine. Online article. 06/06/2017. http://book.mb.net.ua/visnovki-ta-rekomindaci\%D1\%97. (Accessed September 10, 2021). 